\title{
Quantifying RNA and DNA in planktonic organisms with SYBR Green II and nucleases. Part A. Optimisation of the assay*
}

\author{
ELISA BERDALET ${ }^{1}$, CRISTINA ROLDÁN $^{1}$, M. PILAR OLIVAR ${ }^{1}$ \\ and KRISTINE LYSNES ${ }^{2}$ \\ ${ }^{1}$ Institut de Ciències del Mar (CSIC), Passeig Marítim 37-49, 08003 Barcelona, Catalunya, Spain. \\ E-mail: berdalet@icm.csic.es \\ ${ }^{2}$ Department of Microbiology, University of Bergen, Jahnebakken 5, N-5020 Bergen, Norway.
}

\begin{abstract}
SUMMARY: Assay protocols for RNA and DNA in crude plankton extracts using the fluorochrome SYBR Green II are developed here. The method is based on the fluorescence in 3 aliquots: the first measures RNA after DNA digestion; the second measures DNA after RNA digestion; and the third measures residual fluorescence after digestion of both DNA and RNA. This residual fluorescence measurement is critical for accurate calculations of the nucleic acids. Optimisation of the assay conditions are described: fluorochrome concentration, buffer composition, fluorescence stability, temperature and duration of nuclease incubation. In the optimised procedure, the assays are performed in $5 \mathrm{mM}$ Tris buffer (containing 0.9 $\mathrm{mM} \mathrm{CaCl} \cdot 2 \mathrm{H}_{2} \mathrm{O}$ and $0.9 \mathrm{mM} \mathrm{MgCl} \cdot 6 \mathrm{H}_{2} \mathrm{O}, \mathrm{pH} 8.0$ ); DNase and RNase incubations are conducted at $37^{\circ} \mathrm{C}$ for $20 \mathrm{~min}$; the fluorochrome is added to all assays at a final concentration of $3.5 \times 10^{-4}$ and readings are done within the 10-60 min period following the SYBR Green II addition. The study evidenced the importance of the residual fluorescence after nuclease digestion, which is especially taken into account in the calculation of the nucleic acid concentrations. Finally, the variability of the fluorescent response to different RNA and DNA standards is examined; from the performed tests, calculations are based on rRNA from calf liver and DNA from calf thymus standards. The accompanying paper (Berdalet et al., 2005) describes the development of the extraction protocol, as well as the application of both protocols in measuring RNA/DNA ratios in natural plankton samples, and a comparison with ethidium bromide based methods.
\end{abstract}

Key words: SYBR Green II, DNase, RNase, RNA/DNA ratios, plankton.

RESUMEN: CUANTIFICACIÓN DE ARN Y ADN EN ORGANISMOS PLANCTÓNICOS MARINOS MEDIANTE SYBR GREEN II Y NUCLEASES. PARTE A. OPTIMIZACIÓN DEL ENSAYO. - En este trabajo se desarrollan los protocolos para la cuantificación de ARN y ADN en extractos no purificados de plancton utilizando SYBR Green II. El método se basa en la fluorescencia de 3 alícuotas: la primera mide el ARN tras la digestión del ADN; la segunda mide el ADN tras la digestión del ARN y la tercera mide la fluorescencia residual tras la digestión tanto del ARN como del ADN. La medida de esta fluorescencia residual es crítica para obtener una buena estimación de los ácidos nucleicos. Se describen las condiciones de optimización del ensayo: concentración de fluorocromo, composición del tampón, estabilidad de la fluorescencia, temperatura y duración de la incubación con nucleasas. En el procedimiento optimizado los ensayos se realizan en tampón Tris $5 \mathrm{mM}\left(0.9 \mathrm{mM} \mathrm{CaCl} \cdot 2 \mathrm{H}_{2} \mathrm{O}\right.$ y $0.9 \mathrm{mM} \mathrm{MgCl}{ }_{2} \cdot 6 \mathrm{H}_{2} \mathrm{O}, \mathrm{pH}$ 8); las incubaciones con nucleasas se llevan a cabo a $37^{\circ} \mathrm{C}$ durante $20 \mathrm{~min}$; el fluorocromo se añade a todos los ensayos a una concentración final de $3.5 \times 10^{-4}$ y las lecturas se realizan en los 10-60 min posteriores a la adición de SYBR Green II. Este estudio evidencia la importancia de la fluorescencia residual después de la digestión con nucleasas, la cual es especialmente incluída en el cálculo de las concentraciones de ácidos nucleicos. Finalmente, se examinó la variabilidad de la respuesta fluorescente a diferentes patrones de ARN y ADN (rARN de hígado de ternera y ADN de bazo de ternera). La segunda parte de este estudio describe el desarrollo del protocolo de extracción, así como la aplicación de ambos protocolos para medir los cocientes ARN/ADN en muestras de plancton naturales y una comparación con los métodos basados en bromuro de etidio.

Palabras clave: SYBR Green II, nucleasas, cociente ARN/ADN, plancton.

*Received July 17, 2003. Accepted January 10, 2005. 


\section{INTRODUCTION}

Determining the in situ physiological state of marine organisms is one of the main challenges in marine biology and biological oceanography. Many conceptually correct biochemical measurements have been proposed, but their implementation is often hindered by analytical complexities and problems in sampling, calibration and interpretation. The RNA/DNA ratio is one example. The conceptual basis of the RNA/DNA ratio is the covariance of cellular RNA with protein synthesis and growth rate, while DNA remains relatively constant. Cellular DNA varies within a narrow range during the cell division cycle (twofold, in the case of eukaryotic cells), and is highly stable under changing environmental situations (Holm-Hansen et al., 1968; Dortch et al., 1983; Bulow, 1987). Consequently, DNA is a biomass proxy (Holm-Hansen et al., 1968; Regnault and Luquet, 1974), and RNA/DNA ratio is an indicator for the physiological or nutritional status (Bulow, 1970; Sutcliffe, 1970). This conceptual model has advanced our understanding of physiological state in bacteria (e.g. Kemp et al., 1993), phytoplankton (Dortch et al., 1983), microplanktonic communities (Berdalet and Estrada, 1993), zooplankton (Dagg and Littlepage, 1972; Nakata et al., 1994; Saiz et al., 1998; Wagner et al., 1998; Gorokhova and Kyle 2002; Vrede et al., 2002), equinoderma (Klinger et al., 1988) and especially fish larvae and juveniles (e.g. Buckley, 1984; Canino et al., 1991; Clemmesen, 1994; Westerman and Holt, 1994; Folkvord et al., 1996; Kuropat et al. 2002). However, inconsistencies in RNA/DNA ratios in fish larvae and juveniles have been pointed out (e.g. Mathers et al., 1994; Suthers et al., 1996; Bergeron, 1997). Variability in experimental design, field sampling and analytical methodology are the likely cause. Here we focus on problems associated with analytical variability. We aim to optimise the RNA and DNA analysis to facilitate the use of RNA/DNA ratios as proxies of physiological state of microplankton.

Although nucleic acids can be measured spectrophotometrically after lengthy extraction and purification (Schmidt and Tannhauser, 1945; Munro and Fleck, 1966), the procedure lacks the sensitivity needed for small biomasses associated with microplanktonic samples. Increased sensitivity can be achieved using fluorochromes that specifically bind to DNA or that bind to both DNA and RNA, without previous purification or separation of the two molecules. The fluorescence quantum yield of the bound fluo- rochromes is always higher for DNA than for RNA. Unfortunately, until now there has not been a specific fluorochrome for RNA. As a result, it is measured indirectly by subtracting DNA from total nucleic acids. There are two ways in which this can be accomplished. The first is based on using a non-specific fluorochrome such as ethidium bromide (Le Pecq and Paoletti, 1966; Ceasarone et al., 1979; Thoresen et al., 1983) to estimate the total (RNA+DNA) concentration while DNA is quantified on a duplicate sample after RNase digestion. The second consists of estimating DNA with a DNA-specific fluorochrome, in combination with a non-specific stain that simultaneously binds to DNA and RNA in a duplicate sample. Examples of these two-dyes combinations are: DAPI and ethidium bromide (Walser and Güde, 1994), Hoechst 33258 and ethidium bromide homodimer (Mordy and Carlson, 1991) or Hoechst 33258 and thiazole orange (Berdalet and Dortch, 1991). Neither approach yields an independent RNA estimation. This situation has caused uncertainties in RNA measurements, especially with low biomasses. To improve this, Fara et al. (1996), proposed using thiazole orange to quantify RNA and DNA on separate aliquots after digestion with DNase in one and RNase in the other. This fluorochrome is more sensitive than ethidium bromide. Although this methodology has been successfully used (Berdalet et al., 1996a, b; Saiz et al., 1998), independent measurements of RNA and DNA were hampered by residual fluorescence after the nuclease digestion. Certain mathematical corrections were required to calculate nucleic acid concentrations.

Experience using the procedure of Fara et al. (1996), plus the independent development of a new generation of highly sensitive fluorochromes (SYTO, YOYO, YOPRO, SYBR Green I and II, PicoGreen, RiboGreen, etc.) stimulated us to improve the methodology. The new fluorochromes have been synthesised to detect purified nucleic acids in gels (Haugland, 2002). Their suitability for non-purified nucleic acid extracts had to be tested. Here we optimise nucleic acid analysis for marine microplankton. We used the fluorochrome SYBR Green II (Molecular Probes) that binds to both RNA and DNA. According to Schmidt and Ernst (1995), this stain is nearly two orders of magnitude more sensitive than ethidium bromide and about 500 times more sensitive than UV absorption spectroscopy. The research builds on the master thesis (Lysnes, 1998) and the SYBR Green II-nucleic acid digestion research of Berdalet (2002). 
TABLE 1. - Composition of the buffers tested and their suitability expressed as "\% slope" and "\% residual" as defined in section H. When 2 or 3 standard curves were available, the mean values obtained are given.

\begin{tabular}{|c|c|c|c|c|c|c|c|c|c|c|}
\hline \multirow[b]{3}{*}{ DNA Tests } & \multirow{3}{*}{ [Tris] } & \multicolumn{4}{|c|}{ BUFFER COMPOSITION $(\mu \mathrm{M})$} & \multirow[b]{2}{*}{ [EDTA] } & \multirow[b]{2}{*}{$\mathrm{pH}$} & \multirow[b]{2}{*}{$\%$ slope } & \multirow[b]{2}{*}{$\%$ residual } & \multirow[b]{2}{*}{$\mathrm{n}$} \\
\hline & & {$\left[\mathrm{CaCl}_{2}\right]$} & {$\left[\mathrm{MgCl}_{2}\right]$} & {$[\mathrm{NaCl}]$} & [boric] & & & & & \\
\hline & & & & & & & & & & \\
\hline $\mathrm{T} 5+\mathrm{B}$ & 5 & 0.9 & 0.9 & 0 & 89 & 0 & 8.0 & 95.8 & 4.2 & 1 \\
\hline T5 & 5 & 0.9 & 0.9 & 0 & 0 & 0 & 8.0 & 100.0 & 6.3 & 2 \\
\hline T5@pH 7.5 & 5 & 0.9 & 0.9 & 0 & 0 & 0 & 7.5 & 93.2 & 7.5 & 1 \\
\hline T5+EDTA & 5 & 0.9 & 0.9 & 0 & 0 & 0.5 & 8.0 & 108.3 & 8.0 & 1 \\
\hline $\mathrm{T}^{5}+\mathrm{Mg}^{2+}$ & 5 & 0.9 & 5.0 & 0 & 0 & 0 & 8.0 & 86.6 & 8.7 & 1 \\
\hline T100@pH 7.5 & 100 & 0.9 & 0.9 & 0 & 0 & 0 & 7.5 & 65.7 & 9.0 & 1 \\
\hline $\mathrm{T} 100$ & 100 & 0.9 & 0.9 & 0 & 0 & 0 & 8.0 & 75.3 & 11.1 & 1 \\
\hline T5+EDTA@pH 7.5 & 5 & 0.9 & 0.9 & 0 & 0 & 0.5 & 7.5 & 87.6 & 13.2 & 1 \\
\hline $\mathrm{T} 5-\mathrm{Ca}^{2+}+\mathrm{B}$ & 5 & 0 & 0.9 & 0 & 89 & 0 & 8.0 & 101.3 & 17.5 & 1 \\
\hline $\mathrm{T} 100+\mathrm{Na}^{+}$ & 100 & 0.9 & 0.9 & 100 & 0 & 0 & 8.0 & 74.9 & 30.6 & 3 \\
\hline $\mathrm{T} 5-\mathrm{Ca}^{2+}$ & 5 & 0 & 0.9 & 0 & 0 & 0 & 8.0 & 108.8 & 31.4 & 1 \\
\hline \multicolumn{11}{|l|}{ RNA Tests } \\
\hline $\mathrm{T} 5+\mathrm{B}$ & 5 & 0.9 & 0.9 & 0 & 0 & 0 & 8.0 & 58.7 & 10.1 & 1 \\
\hline $\mathrm{T} 5-\mathrm{Ca}^{2+}+\mathrm{B}$ & 5 & 0 & 0.9 & 0 & 0 & 0 & 8.0 & 55.3 & 10.8 & 1 \\
\hline $\mathrm{T} 5$ & 5 & 0.9 & 0.9 & 0 & 0 & 0 & 8.0 & 100.0 & 11.3 & 2 \\
\hline $\mathrm{T} 5-\mathrm{Ca}^{2+}$ & 5 & 0 & 0.9 & 0 & 0 & 0 & 8.0 & 104.1 & 11.4 & 1 \\
\hline $\mathrm{T} 100+\mathrm{Na}^{+}$ & 100 & 0.9 & 0.9 & 100 & 0 & 0 & 8.0 & 128.8 & 35.9 & 1 \\
\hline
\end{tabular}

\section{MATERIALS AND METHODS}

\section{(A) Reagents and solutions}

In this section, we provide information regarding all reagents that have been used to develop our SYBR Green II-nucleases assay method. The solutions used in the Final procedure are summarised at the end of this section.

\section{Buffers}

Several buffers were tested to optimise conditions for the SG-II assay. The characteristics of each component will be found in Section $\mathrm{H}$ and Table 1. In the final procedure the assay is run in Tris buffer. All chemicals used were analytical grade. Tris (Tris(hydroxymethyl)-aminomethane Sigma 7-9®, $\mathrm{T}-1378)$ and $\mathrm{Na}_{2}$ EDTA (E-5134) were obtained from Sigma; $\mathrm{NaCl}$ (\#6404), $\mathrm{MgCl}_{2} \cdot 6 \mathrm{H}_{2} \mathrm{O}$ (\#5833), $\mathrm{CaCl}_{2} \cdot 2 \mathrm{H}_{2} \mathrm{O}$ (\#2382) and Boric acid (\#1.00165) were from Merck. Buffers were made using $0.2 \mu \mathrm{m}$ filtered Milli-Q water. The buffer solutions were autoclaved and kept at room temperature (RT).

\section{Nucleases}

RNase-free DNase (\#776785) and DNase-free RNase (\#1119915) were obtained from Boehringer Mannheim. The concentrations of each working solution (WS) and the final concentrations in the assays had been established by Fara et al. (1996). The DNase vial stock $(1 \mathrm{ml})$ contains 10000 units $\mathrm{ml}^{-1}$ and the RNase vial stock $(1 \mathrm{ml})$ contains 500 $\mu \mathrm{g} \mathrm{ml}^{-1}$. Each WS for the two nucleases is made by diluting the stock solution 1:50 in Tris buffer; from the two WSs, $50 \mu \mathrm{l}$ are used per $1 \mathrm{ml}$ assay so that the final concentration of the DNase and RNase are 10 units $\mathrm{ml}^{-1}$ and $0.5 \mu \mathrm{g} \mathrm{ml}^{-1}$ respectively. DNase requires cations, namely $\mathrm{Ca}^{2+}$ and $\mathrm{Mg}^{2+}$; so $\mathrm{CaCl}_{2} \cdot 2 \mathrm{H}_{2} \mathrm{O}$ and $\mathrm{MgCl}_{2} \cdot 6 \mathrm{H}_{2} \mathrm{O}$, both at $18 \mathrm{mM}$, are included in the DNase WS-A (see the last part of this section), to allow a final $0.9 \mathrm{mM}$ concentration of the two salts in the assay. To minimise differences among the three assays in the final procedure, $\mathrm{Ca}^{2+}$ and $\mathrm{Mg}^{2+}$ are also included in the RNase WS-B but not in the RNase WS-C (end of Section A and Section $\mathrm{H})$. The stock solutions are kept frozen $\left(-20^{\circ} \mathrm{C}\right)$. The WSs are always made on the day of use and maintained on ice during the procedure except for the incubation period.

\section{Fluorochromes}

SYBR Green II (hereafter, SG-II) RNA gel stain (S-7564) was purchased from Molecular Probes, and ethidium bromide (\#16053-9) from Sigma. We strongly endorse the recommendations of the manufacturer regarding the correct manipulation of the fluorochromes. Little is known about the mutagenic properties of SG-II. However, this fluorochrome is close to SYBR Green I (SG-I; Haugland, 2002) and 
SYBR Safe DNA gel Stain (http://www.probes. com/products/sybrsafe/), which are less mutagenic than ethidium bromide. Nevertheless, because SG-II may penetrate living cells, care to avoid skin contact must be taken.

SG-II is provided as a $10000 \mathrm{X}$ concentrate stock solution $(500 \mu \mathrm{l})$ in DMSO, but the molecular weight is not indicated. Thus, the absorbance at 480 $\mathrm{nm}\left(\mathrm{A}_{480}\right.$, corresponding to the absorption maximum in $5 \mathrm{mM}$ Tris buffer, $\mathrm{pH} \mathrm{8.0)} \mathrm{can} \mathrm{be} \mathrm{used} \mathrm{as} \mathrm{an} \mathrm{indi-}$ cator of the relative concentration of different dilutions (Nobel and Furhman, 1997).

Titration curves (Section E) demonstrated that 50 $\mu l$ of WS per $1 \mathrm{ml}$ assay was sufficient, so the final concentration of the fluorochrome in the assay is a $3.5 \times 10^{-4}$ dilution of the stock with an $\mathrm{A}_{480}$ of $0.216 \pm$ 0.002 (mean \pm standard error, 3 batchs of SG-II stocks).

To prepare daily WSs of SG-II, both the fluorochrome and the buffer must reach RT. The WS is made by diluting the stock solution in the chosen buffer 7:1000, and it is maintained at RT in the dark. Before using it (for fluorescence or absorbance measurements), allow the freshly made SG-II WS to stabilise for $30 \mathrm{~min}$.

To avoid the variability related to different fluorochrome batches, use the same SG-II stock for an entire experiment. For instance, $c a$. 250-300 samples with the necessary standard curves can be run over 10-12 days of analyses. During such a period, the repeated cycles of thawing and freezing of the SG-II stock did not cause changes in the fluorochrome solution. Alternatively, the stock solution can be distributed in small aliquots and stored dark at $-20^{\circ} \mathrm{C}$. However, after about 3 months of storage, precipitates form in the aliquots and the fluorometric response can decrease markedly.

In the preliminary tests using SG-I (S-7653), its concentration was set at $1 \times 10^{-4}$, following the recommendations of Molecular Probes.

\section{Nucleic acid standards}

Nucleic acid standard curves were run, in the different phases of our study, using different types of RNA and DNA standards (all from Sigma). We will refer to them abbreviated as follows: RNA type III from baker's yeast (R-7125; RNA-Y); rRNA from calf liver, 18S and 28S (R-0889; rRNA-L); RNA from Escherichia coli strain W (R-7628; RNA-Ec); DNA Type I from calf thymus soluble form (D-3664; DNA-T); DNA from calf thymus, genomic, ultrapure
(D-4764; uDNA-T); and DNA from E. coli strain B (D-2001; DNA-Ec). Of two codes within parentheses, the first is Sigma's, the second is ours. Purity and concentration of the RNA and DNA stock standard solutions were regularly checked by measuring their UV absorbances (Sambrook et al., 1989).

The storage and aliquoting of the stock and WSs were experimentally established based on criteria of maximum UV absorbance stability and minimum fluorescence variability of the standard curves. rRNA-L is provided as a $2 \mathrm{mg} \mathrm{ml}^{-1}$ solution and is stored frozen $\left(-80^{\circ} \mathrm{C}\right)$; from it an intermediate solution is made (e.g. $20 \mu \mathrm{g} \mathrm{ml}^{-1} \mathrm{RNA}$, in Tris buffer), aliquoted and stored frozen $\left(-80^{\circ} \mathrm{C}\right)$. One aliquot is used to obtain the fresh WS (e.g. $5 \mu \mathrm{g} \mathrm{ml}^{-}$ ${ }^{1}$ RNA, in Tris buffer) for every day of analysis. For all powdered standards, the stock solutions (25 $\mathrm{mg} \mathrm{ml}^{-1} \mathrm{RNA}$ and $200 \mu \mathrm{g} \mathrm{ml}^{-1}$ DNA) were made in deionised water and stored at $4^{\circ} \mathrm{C}$. Intermediate solutions (25 $\mu \mathrm{g} \mathrm{ml}^{-1}$ RNA and $20 \mu \mathrm{g} \mathrm{ml}^{-1}$ DNA) were prepared in the required buffer and kept at $4^{\circ} \mathrm{C}$. The intermediate standard solutions were made in a sufficient volume to generate daily WSs (e.g. $5 \mu \mathrm{g} \mathrm{ml}^{-1}$ RNA and $4 \mu \mathrm{g} \mathrm{ml}^{-1}$ DNA) to cover every series of analysis. If manipulated with caution, these intermediate solutions are stable for about 1 year. rRNA-L and DNA-T are proposed for the final procedure as discussed in Section I. Note that the concentration of the RNA WS is higher than that of the DNA. Given the lower fluorescence yield of RNA (Fig. 1), this generates standard curves that can be read at the same sensitivity (scale, voltage) of the spectrofluorometer.

\section{Vessels}

The glassware was soaked in $5 \% \mathrm{HCl}$, thoroughly rinsed with Milli-Q water, and heated at $450^{\circ} \mathrm{C}$ for $5 \mathrm{~h}$. New sterile plasticware was used; when necessary and possible, it was also autoclaved.

\section{Summary of solutions for the final procedure}

The following solutions are required for the application of the final assay procedure (Section $\mathrm{K}$ ):

Tris buffer: $5 \mathrm{mM}$ Tris ( $\mathrm{pH} 8.0$ ) used to prepare all WSs and in the assays. Keep at RT.

$\mathrm{Ca}^{2+}$ stock solution: $900 \mathrm{mM} \mathrm{CaCl} \cdot 2 \mathrm{H}_{2} \mathrm{O}$ in Tris buffer. Keep at RT.

$\mathrm{Mg}^{2+}$ stock solution: $900 \mathrm{mM} \mathrm{MgCl}_{2} \cdot 6 \mathrm{H}_{2} \mathrm{O}$ in Tris buffer. Keep at RT.

DNase WS-A: To be added in the Tube A and 
Tube $\mathrm{C}$ series, and to run the RNA+DNase and the DNA+DNase standard curves. Prepare fresh (50 $\mu \mathrm{l}$ per assay) by diluting 1:50 the DNase, the $\mathrm{Ca}^{2+}$ and the $\mathrm{Mg}^{2+}$ stock solutions in Tris buffer. Keep on ice until use.

RNase WS-B (with cations): To be added to the Tube B series, and to run the RNA+RNase and the DNA+RNase standard curves. Prepare fresh (50 $\mu 1$ per assay) by diluting 1:50 the RNase, the $\mathrm{Ca}^{2+}$ and the $\mathrm{Mg}^{2+}$ stock solutions in Tris buffer. Keep on ice until use.

RNase WS-C (without cations): To be added to the Tube $\mathrm{C}$ series only. Prepare fresh $(50 \mu \mathrm{l}$ per assay) by diluting 1:50 the RNase stock solution in Tris buffer.

SG-II WS: Allow the stock solutions and aliquots to gently thaw and stabilise at RT. Dilute the stock solution 7:1000 in Tris buffer; prepare enough for all samples and standards assays $(50 \mu \mathrm{l}$ per $1 \mathrm{ml}$ assay) to run in one day. Allow the SG-II WS to stabilise for $30 \mathrm{~min}$ at RT and measure its $\mathrm{A}_{480}$ afterwards. This final dilution in the assay must have an $\mathrm{A}_{480}$ of $c a .0 .216$; otherwise, dilute accordingly. The fluorochrome must be protected from light throughout as recommended by Molecular Probes.

rRNA-L (R-0889) standard WS: Prepare an intermediate solution in Tris buffer to cover a series of analyses (e.g. $1 \mathrm{ml}, 20 \mu \mathrm{g} \mathrm{ml}^{-1}$ ), divide into small aliquots (e.g. $50 \mu \mathrm{l}$ ) and store at $-80^{\circ} \mathrm{C}$. From it, make the fresh RNA WS (e.g. $5 \mu \mathrm{g} \mathrm{ml}^{-1}$ ) in Tris buffer. The concentration range covered by the standard curve (e.g. 0-150 ng ml-1) will depend on the biomass of the samples.

DNA-T (D-3664) standard WS: Prepare an intermediate solution in Tris buffer to cover a series of analyses (e.g. $1 \mathrm{ml}, 20 \mu \mathrm{g} \mathrm{ml}^{-1}$ ) and store at $4^{\circ} \mathrm{C}$. From it, make the fresh DNA WS (e.g. $4 \mu \mathrm{g} \mathrm{ml}^{-1}$ ) in Tris buffer. The concentration range covered by the standard curve (e.g. 0-120 $\mathrm{ng} \mathrm{ml}^{-1}$ ) will depend on the biomass of the samples.

\section{(B) Fluorescence readings}

This study started using the Shimadzu RF-570 spectrofluorometer and it continued with the Aminco-Bowman 2 (AB2), which features temperature controlled cuvette holders and higher sensitivity. The fluorescence spectra of the fluorochromes in each apparatus followed the pattern indicated by the manufacturer, although the maximum excitation and emission wavelengths varied slightly. Samples stained with SG-II were read in the Shimadzu RF-
570 spectrofluorometer, at 490/520 nm (Ex/Em maxima), using a $5 \mathrm{~nm}$ bandwidth. In the $\mathrm{AB} 2$, the $\mathrm{Ex} / \mathrm{Em}$ maxima were found at $497 / 511 \mathrm{~nm}$ and a 4 $\mathrm{nm}$ bandwidth was used. The tests with SG-I were read at 497/520 nm (Ex/Em), $5 \mathrm{~nm}$ bandwidth, using the Shimadzu RF-570 spectrofluorometer. The excitation and emission maxima of SYBR Green I and II are situated in the visible part of the spectrum, permitting fluorescence readings to be made with either quartz or glass cuvettes.

The stability of the spectrofluorometers was checked periodically by running fluorescein standard curves (F-7137, from Sigma). This highly stable fluorescent molecule has excitation and emission peaks close to those of SG-I and SG-II. Both fluorochromes were calibrated against fluorescein on the two spectrofluorometers. This way their fluorescence could be expressed as fluorescein equivalent units (FEU, in $\mathrm{nM})$. The regression equation for the two spectrofluorometers were:

$$
\begin{array}{ll}
\mathrm{AB} 2 \text { at 730V: } & \mathrm{F}_{\mathrm{AB}}=1.404 *[\mathrm{nM}]-0.007 ; \\
& \mathrm{r}=0.99998 \\
\text { Shimadzu RF-570: } & \mathrm{F}_{\mathrm{S}}=1.227 *[\mathrm{nM}]+0.200 ; \\
& \mathrm{r}=0.99637
\end{array}
$$

From these two equations the FEU for any SG-II or SG-I could be calculated.

\section{(C) Natural samples}

Most of the work here was performed on RNA and DNA standards. Natural samples were used for the experiment indicated in Section J. The details of the manipulation procedure for natural samples is given in the accompanying paper (Berdalet et al., 2005).

\section{EXPERIMENTAL: DEVELOPMENT OF THE SG-II AND NUCLEASES PROCEDURE}

Here we describe selected experiments for the development of the final analytical methodology, which is described in the Results and Discussion $\mathrm{K}$ section.

\section{(D) Choice between SG-I and SG-II}

\section{Rationale}

A preliminary test was conducted comparing the fluorescence response of SG-I and SG-II after bind- 

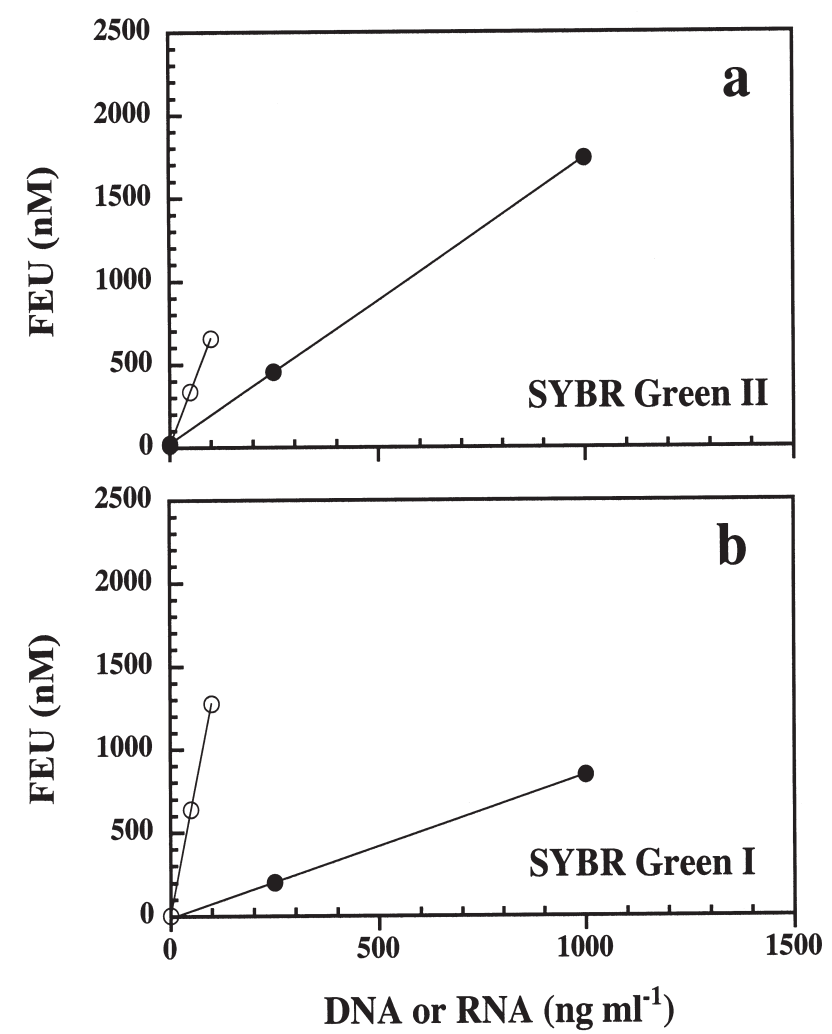

FIG. 1. - Comparative fluorescence response of RNA (RNA-Ec, closed symbols) and DNA (DNA-Ec, open symbols) standards stained with SG-II (a) and SG-I (b). Readings performed with the RF-570 spectrofluorometer.

ing to RNA and DNA. RNA (RNA-Ec) and DNA (DNA-Ec) standard curves were run using the two fluorochromes in "T100+Na+" buffer (Table 1).

\section{Findings}

Figure 1 illustrates the RNA and DNA standard curves run with SG-II (Fig. 1a) or SG-I (Fig. 1b). The two fluorochromes showed higher sensitivity for DNA than for RNA. This is common to all stains that bind to both nucleic acids. However, for DNA the fluorescent response of SG-I was higher than that of SGII. For RNA, the response of SG-II was higher. Since RNA is the more difficult to measure, we chose to use SG-II. These results were unexpected because Molecular Probes reports the contrary with gels.

\section{(E) SG-II concentration in the assay}

\section{Rationale}

For RNA gel staining Molecular Probes recommends a 1:10000 dilution of SG-II. Could this concentration be used for the fluorometric quantification of RNA and DNA in plankton extracts?
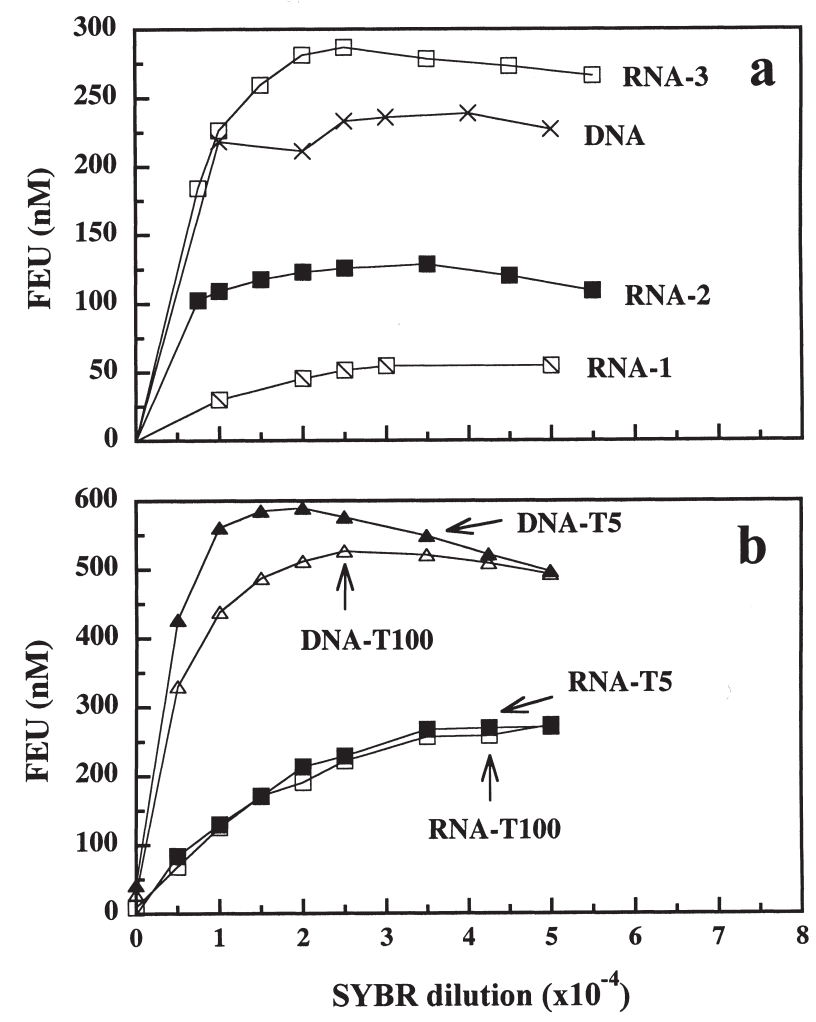

FIG. 2. - (a) Titration curves obtained using "TBE" buffer with 260 ng ml-1 RNA-Y (RNA-1), 260 (RNA-2) or 520 (RNA-3) ng ml ${ }^{-1}$ RNA-Ec, and $214 \mathrm{ng} \mathrm{ml}^{-1}$ DNA-Ec (DNA). (b) Titration curves of $1.36 \mu \mathrm{g} \mathrm{ml}^{-1}$ RNA-Y and $100 \mathrm{ng} \mathrm{ml}^{-1}$ DNA-T on "T5" (RNA-T5, DNA-T5) or "T100+Na+" buffers. Readings performed with the RF-570 spectrofluorometer.

To determine the optimum concentration of SG-II in the assay we ran titration curves by adding increasing amounts of the SG-II WS to fixed quantities of different RNA or DNA standards. Titration curves (Fig. 2) were run in "TBE” buffer (89 $\mathrm{mM}$ Tris, $89 \mathrm{mM}$ boric acid, $1 \mathrm{mM}$ EDTA, $\mathrm{pH}$ 8.0), recommended by Molecular Probes and in other buffers (Section H, Table 1). When the optimum dilution of the SG-II and buffer were established, we measured their $\mathrm{A}_{480}$ using three different stocks of SG-II.

\section{Findings}

Figure 2 shows that the fluorescence response of SG-II increased sharply with increasing dye concentration until it stabilised above $2 \times 10^{-4}$. Although the curves for each buffer were different, the general shape and saturation concentration range was similar. We fixed the dilution at $3.5 \times 10^{-4}$ for our assays run on "T5" buffer, the final buffer selection (Section $\mathrm{H})$. This dilution had an $\mathrm{A}_{480}$ of $0.216 \pm 0.002$ (mean \pm SEM, $\mathrm{n}=3$ ). 
This concentration is only slightly higher than $1 \times 10^{-4}$, the concentration suggested by Molecular Probes, and is similar to the concentration reported by Schmidt and Ernst (1995) for a linear response in the $0-1000 \mathrm{ng} \mathrm{ml}^{-1}$ range of RNA.

\section{(F) Tube selection}

Molecular Probes recommends plastic tubes for solutions containing SG-II, because the fluorochrome does not adsorb to plastic as it does to glass (Haugland, 2002). However, we found that standard curves run in glass tubes were approximately the same as those run on plastic tubes, so reusable glass tubes were chosen.

\section{(G) Temporal stability and temperature dependence of the fluorescence response}

\section{Rationale}

For gel staining with SG-II, Molecular Probes indicates an optimal staining time of 10-40 min for polyacrylamide gels and 20-40 min for agarose gels. For quantitative analyses in plankton extracts, we studied the stability of the fluorescence response of the nucleic acid bound dye.

In a preliminary test, eighteen replicates of 100 ng ml ${ }^{-1}$ RNA-Y in "T100+Na" buffer (Table 1) were stained simultaneously and incubated in the dark at RT. Three replicates were read at six different times from 0 to $160 \mathrm{~min}$. Later, once the final assay procedure was established, a second test (Fig. 3a) was repeated in assays using "T5" buffer (Table 1), $30 \mathrm{ng} \mathrm{ml}^{-1}$ RNA incubated with DNase, and 20 ng ml-1 DNA incubated with RNase (Sections H, I). For each standard (RNA-Y, rRNA-L, DNA-T, uDNA-T), 27 assays were completed and 3 replicates were read at 9 different times from 0 to 180 min. Finally, a similar test was performed on a natural-sample extract (Fig. 3b). From a single homogenate (Berdalet et al., 2005), 63 aliquots were distributed to run the three assays (i.e. DNase, RNase and Residual, Section K), which were read in triplicates at 7 different times from 0 to $120 \mathrm{~min}$. Since fluorescence decreases with increasing temperature, with percentage changes depending on the fluorophore (Bashford, 1987), the SG-II WS was kept dark at RT $\left(22^{\circ} \mathrm{C}\right)$ and added to the test tubes previously equilibrated at RT (c. 2 min). Finally, all readings were performed at the same RT $\left(22^{\circ} \mathrm{C}\right)$ temperature.
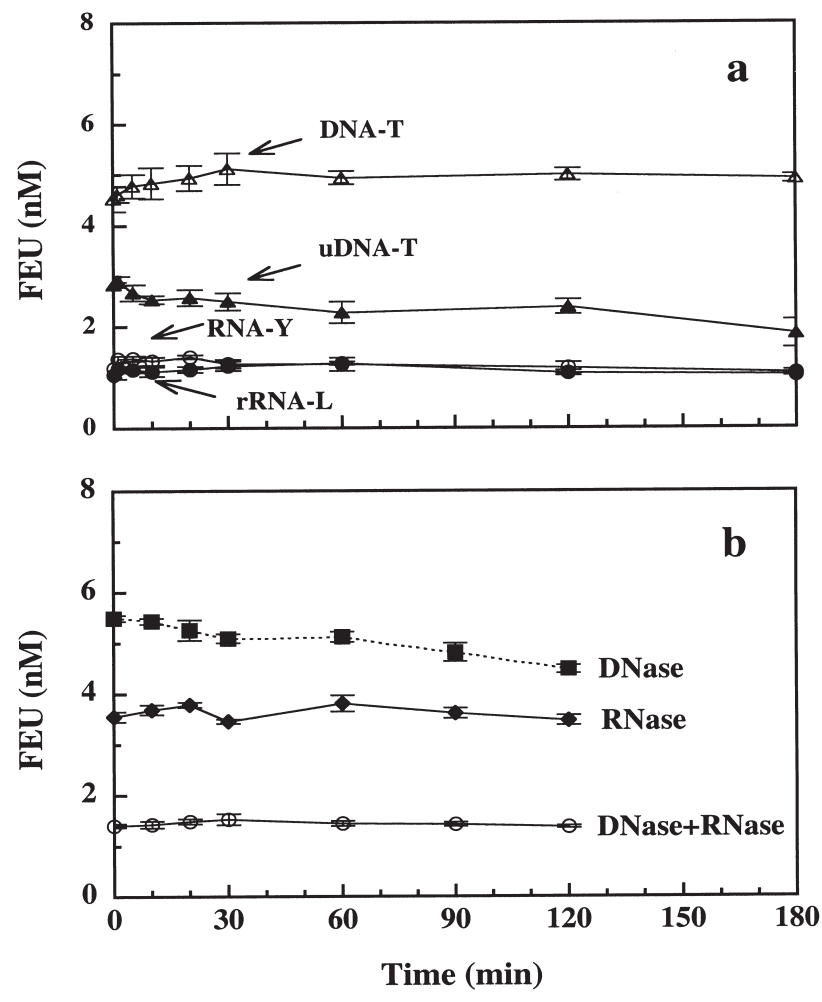

FIG. 3. - Time course of the fluorescence response after staining with SG-II. (a) Test with nucleic acid standards. (b) Test with a natural sample. Vertical bars indicate the standard error (SEM, $n=3$ ). Readings performed with the AB2 spectrofluorometer.

\section{Findings}

In the preliminary approach, the fluorescence of the RNA-bound SG-II dropped sharply (c. 30\%) during the first $10 \mathrm{~min}$ and decreased at a slower rate (ca. 10\%) in the next 10 to $60 \mathrm{~min}$ (not shown). Using the final assay procedure, the fluorescence of the RNA standards was highly stable during the 0180 min period (Fig. 3a); however, for the DNA standards it varied during the first 10 min (Fig. 3a). Regarding the natural sample extract (Fig. 3b), the fluorescence of the three assays remained stable during the 10-60 min period, but tended to decrease afterwards. During this period, the coefficient of variation $(\mathrm{CV} \%$, standard deviation/mean $\mathrm{x} 100)$ of the readings was $5-10 \%$.

In summary, readings are performed within the 10-60 min period following the SG-II addition; meanwhile the samples are kept dark at RT $\left(22^{\circ} \mathrm{C}\right)$.

\section{(H) Assay buffer selection}

\section{Rationale}

The composition of the assay buffer that optimised the RNA and DNA digestion by the nucleas- 
es and the fluorescent yield of SG-II after binding to the nucleic acids was investigated. The Tris buffer (100 mM Tris, $100 \mathrm{mM} \mathrm{NaCl}, 0.9 \mathrm{mM} \mathrm{CaCl} \cdot 2 \mathrm{H}_{2} \mathrm{O}$ and $0.9 \mathrm{mM} \mathrm{MgCl}_{2} \cdot 6 \mathrm{H}_{2} \mathrm{O}$ ) used by Fara et al. (1996) and Berdalet (2002) was the starting point of the tests. The aspects studied were (Table 1): $\mathrm{pH}$ (7.5 or $8.0)$; Tris concentration $(5 \mathrm{mM}$ or $100 \mathrm{mM})$; presence $(100 \mathrm{mM})$ or absence of $\mathrm{Na}^{+}$; concentration of $\mathrm{Mg}^{2+}(0.9 \mathrm{mM}$ or $5 \mathrm{mM})$; presence of EDTA (0.5 $\mathrm{mM})$; presence of boric acid $(89 \mathrm{mM})$; and presence $(0.9 \mathrm{mM})$ or absence of $\mathrm{Ca}^{2+}$. The WSs of the RNA and DNA standards and of the two nucleases were made fresh for every experiment. Most tests were done on DNA because the DNase effectiveness is more sensitive to the chemical conditions of the assay than that of RNase. The nuclease incubation procedure is described in Section I.

The suitability of each buffer was evaluated (Table 1 ) in terms of "\% slope" and "\% residual". "\%slope" accounts for the degree of fluorescence response of the SG-II after binding to the nucleic acids; the slope obtained for each buffer is expressed as the proportion $(\%)$ of the slope obtained in the "T5" buffer. To minimise the day-to-day variability, a standard curve of DNA (or RNA) in the "T5" buffer was conducted every day as a reference. The term "\% residual" identifies the residual fluorescence fraction after the nuclease digestion. It is calculated by dividing the slope of the DNA standard curve run in the presence of DNase (or of RNA incubated with RNase) by the slope of the DNA (or RNA) standard curve run without the corresponding degrading enzyme. In general, only one standard curve was run for each buffer tested, except for the "T5" and "T100+Na" buffers, for which we include the results of 2 or 3 curves.

\section{Findings}

In Table 1, the buffers are ranked according to the "\% residual" fluorescence obtained: from "T5+B" to "T5-Ca ${ }^{2+}$ " in the upper part of the table (DNA tests), or to "T100+Na+" in the lower part (RNA tests).

The presence of $100 \mathrm{mM} \mathrm{NaCl}$ ("T100+ $\mathrm{Na}^{+}$" buffer) produced one of the highest residual fluorescence after the digestion by DNase (range: 26.4$36.5 \%$; mean: $30.6 \%$ ) or RNase (35.9\%) respectively. On the other hand, the presence of $100 \mathrm{mM} \mathrm{NaCl}$ had an opposite effect in the fluorescent response of the nucleic acids: the slope of DNA in "T100+Na+" was lower than in "T5" (74.9\% vs $100 \%$ slope) and higher in the case of RNA (128.8\% vs 100\%). The elimination of $\mathrm{NaCl}$ ("T100") in the DNA tests did not improve the fluorescence $(75.3 \%$ vs $74.9 \%$ slope) although the DNase was more effective (11.1\% vs $30.6 \%$ residual). The results motivated us to eliminate $\mathrm{NaCl}$ from the buffer. The inhibitory effect on DNase activity by $\mathrm{NaCl}$ at concentrations above $100 \mathrm{mM}$ had already been noted by Bentle $e t$ al. (1981).

Reducing the Tris concentration in the DNA tests from $100 \mathrm{mM}$ to $5 \mathrm{mM}$ ("T100" vs "T5" buffer) had a minimum effect on the DNase digestion $(11.1 \%$ vs $6.3 \%$ residual), although the fluorescence response of DNA improved (75\% vs 100\% slope). Because Schmidt and Ernst (1995) recommend avoiding high $(>10 \mathrm{mM})$ Tris concentrations, and on the basis of our results, we fixed the concentration of Tris at 5 $\mathrm{mM}$. This concentration is also used by Caldarone et al. (2001) for the ethidium bromide procedure.

The two cations, $\mathrm{Ca}^{2+}$ and $\mathrm{Mg}^{2+}$, both at $0.9 \mathrm{mM}$ in a $5 \mathrm{mM}$ Tris buffer ("T5" buffer), offered acceptable levels of DNA (6.3\%) and RNA (11.3\%) residual fluorescences without causing a major decrease in the fluorescence response of DNA or that of RNA. Indeed, the elimination of $\mathrm{Ca}^{2+}$ ("T5- $\mathrm{Ca}^{2+}$ " buffer) resulted in high residual fluorescence after DNase digestion (31.4\%). Furthermore, increasing the $\mathrm{Mg}^{2+}$ concentration up to $5 \mathrm{mM}$ (the concentration recommended by Boehringer Mannheim for the DNase assay) in the presence of $\mathrm{Ca}^{2+}$ ("T5+ $\mathrm{Mg}^{2+}$ "buffer) did not improve the DNase effectiveness (8.7\% residual). Thus, the concentration of the two cations was set at $0.9 \mathrm{mM}$. The sensitivity to salts (ionic strength) has also been reported for SG-II (Schmidt and Ernst, 1995) as well as for other DNA fluorochromes such as Pico Green and SYTOX Green (Marie et al., 1996, Veldhuis et al., 1997). Interestingly, our choice of 0.9 $\mathrm{mM}$ is close to the one established by Bentle et al. (1981) $\left(0.8\right.$ and $1.0 \mathrm{mM}$, respectively, for $\mathrm{Ca}^{2+}$ and $\mathrm{Mg}^{2+}$ ) for the sequential enzymatic quantification of DNA and RNA by ethidium bromide and also used by Caldarone et al. (2001).

Molecular Probes recommends the "TBE" buffer (89 mM Tris, $89 \mathrm{mM}$ boric acid, $1 \mathrm{mM}$ EDTA, $\mathrm{pH}$ 8.0) and a $\mathrm{pH}$ range of 7.5-8.3. The presence of 89 $\mathrm{mM}$ boric acid in a $5 \mathrm{mM}$ Tris buffer ("T5+B" buffer) favoured the DNase activity (a minimum 4.2\% DNA residual fluorescence was obtained) but, in contrast, the fluorescence response of RNA decreased markedly (58.7\% of that on "T5" buffer). To test whether the cations required for the DNase digestion interfered with the boric acid, we ran standard curves in the presence of boric acid without $\mathrm{Ca}^{2+}$ ("T5-Ca ${ }^{2+}+\mathrm{B}$ " buffer). The elimination of $\mathrm{Ca}^{2+}$ 
TABLE 2. - Example of the composition of the assays ( $\mu 1$ per $1 \mathrm{ml}$ assay) prepared to run the standard curves illustrated in Fig. 4 and their corresponding regression lines obtained. The reagents are described at the end of section A. In the final procedure (section K), the calculations are based on the RNA+DNase, the RNA+RNase, the DNA+RNase and the DNA+DNase standard curves. "1\% STEB": extraction buffer (1\% sarcosine, $5 \mathrm{mM}$ Tris and $1 \mathrm{mM}$ EDTA, pH 8.0).

\begin{tabular}{|c|c|c|c|c|c|c|c|}
\hline \multicolumn{8}{|c|}{$\operatorname{FEU}(\mathrm{nM})=31.27+0.85532 \times\left(\mathrm{ng} \mathrm{RNA} \mathrm{ml} \mathrm{m}^{-1}\right)$} \\
\hline Tube & $\mathrm{ng} / \mathrm{ml}$ RNA & RNA $5 \mu \mathrm{g} / \mathrm{ml}$ & DNase w.s.-A & RNase w.s.-B & $1 \% \mathrm{STEB}$ & SYBR & Tris buffer \\
\hline $\mathrm{R} 1$ & 0 & 0 & 0 & 0 & 2.5 & 50 & 947.5 \\
\hline R2 & 50 & 10 & 0 & 0 & 2.5 & 50 & 937.5 \\
\hline R3 & 100 & 20 & 0 & 0 & 2.5 & 50 & 927.5 \\
\hline $\mathrm{R} 4$ & 150 & 30 & 0 & 0 & 2.5 & 50 & 917.5 \\
\hline \multicolumn{8}{|c|}{ RNA+DNase $\quad$ FEU $(n M)=28.92+0.8608 \times\left(n g\right.$ RNA ml $\left.{ }^{-1}\right)$} \\
\hline Tube & $\mathrm{ng} / \mathrm{ml} \mathrm{RNA}$ & RNA $5 \mu \mathrm{g} / \mathrm{ml}$ & DNase w.s.-A & RNase w.s.-B & $1 \%$ STEB & SYBR & Tris buffer \\
\hline RD1 & 0 & 0 & 50 & 0 & 2.5 & 50 & 897.5 \\
\hline RD2 & 50 & 10 & 50 & 0 & 2.5 & 50 & 887.5 \\
\hline RD3 & 100 & 20 & 50 & 0 & 2.5 & 50 & 877.5 \\
\hline RD4 & 150 & 30 & 50 & 0 & 2.5 & 50 & 867.5 \\
\hline \multicolumn{8}{|c|}{ RNA+RNase $\quad$ FEU $(n M)=30.08+0.09948 x\left(n g\right.$ RNA ml $\left.{ }^{-1}\right)$} \\
\hline Tube & $\mathrm{ng} / \mathrm{ml} \mathrm{RNA}$ & RNA $5 \mu \mathrm{g} / \mathrm{ml}$ & DNase w.s.-A & RNase w.s.-B & $1 \%$ STEB & SYBR & Tris buffer \\
\hline RR1 & 0 & 0 & 0 & 50 & 2.5 & 50 & 897.5 \\
\hline RR2 & 50 & 10 & 0 & 50 & 2.5 & 50 & 887.5 \\
\hline RR3 & 100 & 20 & 0 & 50 & 2.5 & 50 & 877.5 \\
\hline RR4 & 150 & 30 & 0 & 50 & 2.5 & 50 & 867.5 \\
\hline \multicolumn{8}{|c|}{$\operatorname{FEU}(\mathrm{nM})=23.54+4.9835 \times\left(\mathrm{ng}\right.$ DNA ml$\left.{ }^{-1}\right)$} \\
\hline Tube & $\mathrm{ng} / \mathrm{ml} \mathrm{DNA}$ & DNA $4 \mu \mathrm{g} / \mathrm{ml}$ & DNase w.s.-A & RNase w.s.-B & $1 \%$ STEB & SYBR & Tris buffer \\
\hline D1 & 0 & 0 & 0 & 0 & 2.5 & 50 & 947.5 \\
\hline D2 & 40 & 10 & 0 & 0 & 2.5 & 50 & 937.5 \\
\hline D3 & 80 & 20 & 0 & 0 & 2.5 & 50 & 927.5 \\
\hline D4 & 120 & 30 & 0 & 0 & 2.5 & 50 & 917.5 \\
\hline \multicolumn{8}{|c|}{ DNA+RNase $\quad$ FEU $(n M)=18.83+4.8963 x\left(n g\right.$ DNA ml $\left.{ }^{-1}\right)$} \\
\hline Tube & $\mathrm{ng} / \mathrm{ml} \mathrm{DNA}$ & DNA $4 \mu \mathrm{g} / \mathrm{ml}$ & DNase w.s.-A & RNase w.s.-B & $1 \%$ STEB & SYBR & Tris buffer \\
\hline DR1 & 0 & 0 & 50 & 0 & 2.5 & 50 & 897.5 \\
\hline DR2 & 40 & 10 & 50 & 0 & 2.5 & 50 & 887.5 \\
\hline DR3 & 80 & 20 & 50 & 0 & 2.5 & 50 & 877.5 \\
\hline DR4 & 120 & 30 & 50 & 0 & 2.5 & 50 & 867.5 \\
\hline \multicolumn{8}{|c|}{ DNA+DNase $\quad$ FEU $(n M)=24.70+0.5175 x\left(n g\right.$ DNA ml $\left.{ }^{-1}\right)$} \\
\hline Tube & $\mathrm{ng} / \mathrm{ml} \mathrm{DNA}$ & DNA $4 \mu \mathrm{g} / \mathrm{ml}$ & DNase w.s.-A & RNase w.s.-B & $1 \%$ STEB & SYBR & Tris buffer \\
\hline DD1 & 0 & 0 & 0 & 50 & 2.5 & 50 & 897.5 \\
\hline DD2 & 40 & 10 & 0 & 50 & 2.5 & 50 & 887.5 \\
\hline DD3 & 80 & 20 & 0 & 50 & 2.5 & 50 & 877.5 \\
\hline DD4 & 120 & 30 & 0 & 50 & 2.5 & 50 & 867.5 \\
\hline
\end{tabular}

increased the DNA residual fluorescence (17.5\%) and did not result in any positive effect of boric acid, indicative of a certain interference between boric acid and the cations. Thus, boric acid was discarded.

The addition of EDTA completely inhibited DNase at high concentration $(10 \mathrm{mM}$ EDTA in "T100+Na+" buffer, not included in Table 1), probably because of a chelator effect on the cations required for the nuclease digestion. However, at a lower concentration $(0.5 \mathrm{mM}$, in "T5+EDTA" and "T5+EDTA pH 7.5" buffers), it had a minimum effect, regardless of the $\mathrm{pH}$ tested (8.0 or $13.2 \%$ residual at $\mathrm{pH} 8.0$ or 7.5 respectively). Thus, EDTA was not included in the final buffer.

Concerning $\mathrm{pH}$, the best fluorescent response was obtained at $\mathrm{pH} 8.0$, with no effect on the residual fluorescence ("T5" vs "T5 pH 7.5"; or "T100" vs “T100 pH 7.5").
In summary, the best equilibrium between fluorescence response and nuclease effectiveness was obtained with a $5 \mathrm{mM}$ Tris buffer ( $\mathrm{pH} 8.0$ ) containing $0.9 \mathrm{mM} \mathrm{CaCl}_{2}$ and $0.9 \mathrm{mM} \mathrm{MgCl}$ ("T5"). This buffer was selected to conduct the assays of the SGII procedure.

In practice, this $5 \mathrm{mM}$ Tris buffer is used throughout. $\mathrm{Ca}^{2+}$ and $\mathrm{Mg}^{2+}$, needed only for the DNase activity, are supplied through the nuclease WSs as indicated in Section A to avoid differences among the three assays of the final procedure.

\section{(I) Nuclease incubations}

\section{Rationale}

To optimise nuclease effectiveness we took into account the temperature and reaction time of the 

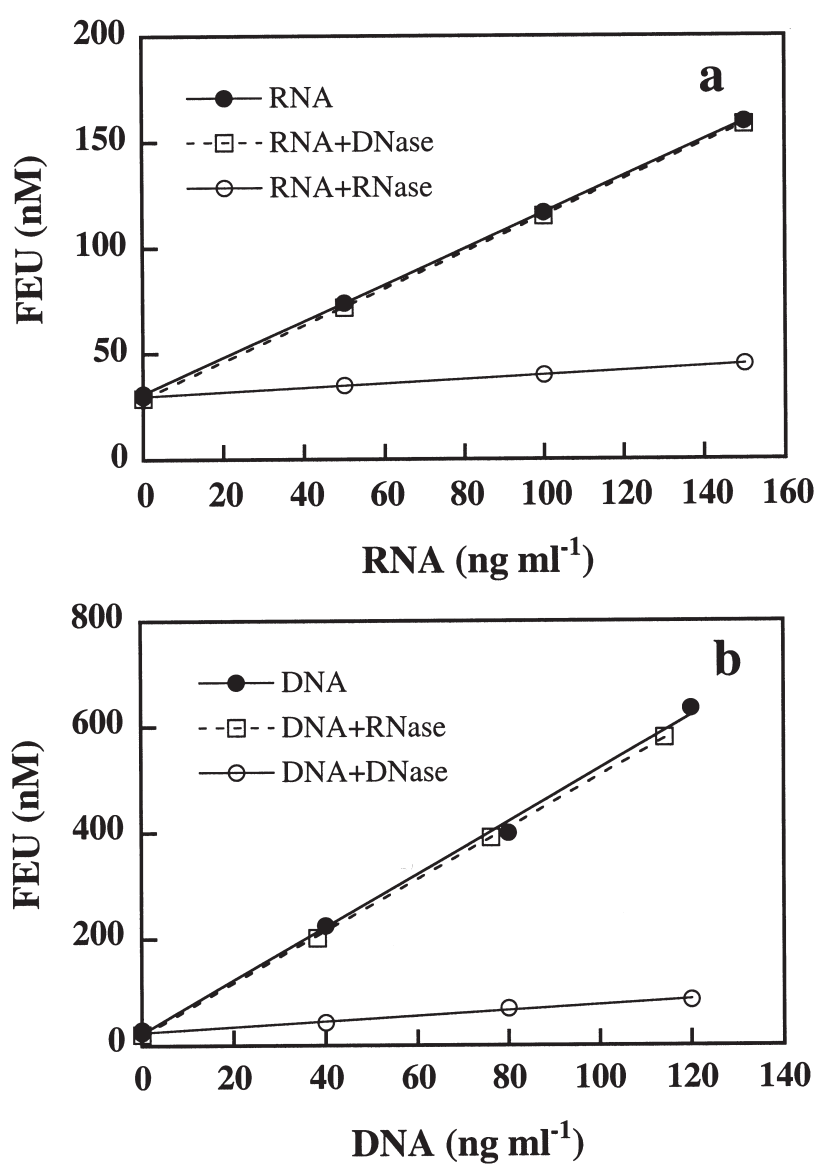

FIG. 4. - RNA (a) and DNA (b) standard curves run alone and in the presence of the two nucleases (readings performed with the RF-570 spectrofluorometer). The RNA and DNA standard curves without nucleases illustrate the specificity of the high purity nucleases (section I). The calculation of the RNA concentration (section K) is based on the slope of the RNA standard curve run in the presence of DNase $\left(m_{B N}-\right.$ and on the RNase residual fluorescence fraction $(\rho)$ obtained as the ratio between the slope RNA standard curve after digestion by RNase $\left(\mathrm{m}_{\mathrm{RNA}+\mathrm{RNase}}\right)$ and the $\mathrm{m}_{\mathrm{RNA}+\mathrm{DNase}}$. The analogous figure concerns the DNA calculations (based on the estimation of $m_{D N A+R N a s e}$ and $\delta$ ). The composition of the assays of each standard curves run and their corresponding regression lines obtained are given in Table 2.

nuclease incubations and we verified the nuclease specificity.

The incubation temperature is often $37^{\circ} \mathrm{C}$ for RNase and $25^{\circ} \mathrm{C}$ for DNase (Fara et al., 1996 and Boehringer Mannheim). However, here DNase effectiveness was higher at $37^{\circ} \mathrm{C}$ than at $25^{\circ} \mathrm{C}$ (without affecting RNA) in tests using thiazole orange (Berdalet, unpublished data). Thus, the temperature of both incubations was fixed at $37^{\circ} \mathrm{C}$ in the procedure with SG-II, without further tests.

We tested whether the effectiveness of the nucleases was improved by increasing the incubation time from 20 to 60 min. RNA-Y and rRNA-L standard curves were incubated with RNase for both times in "T5" buffer, and the fluorescence response was compared with an RNA standard curve run without the enzyme. The analogous test was conducted on DNA-T and uDNA-T. Increasing the incubation time up to $60 \mathrm{~min}$ did not reduce the residual fluorescences (not shown).

Besides using RNase-free DNase and DNasefree RNase, we verified that the DNase incubation did not degrade RNA and that the DNase-free RNase incubation did not affect DNA. RNA or DNA standard curves were run with or without nucleases, as indicated in Table 2. These tests were conducted on RNA-Y, rRNA-L, DNA-T and uDNA$\mathrm{T}$, and with different buffers.

\section{Findings}

RNA or DNA standard curves conducted without nucleases were not significantly different from those obtained with the nucleases (Fig. 4, Table 2). In the final procedure, nuclease incubations of nucleic acids were performed in a $37^{\circ} \mathrm{C}$ water bath for $20 \mathrm{~min}$ in the selected buffer. To stop the reaction, the tubes were immersed in an ice bath. Incubation always preceded staining. For calculations (Section K), standards must be treated as samples. Consequently, standard curves included incubation of the RNA and DNA standards with nucleases (Section K).

\section{RESULTS AND DISCUSSION}

From the previous section we can summarise the essential points of the SG-II and nucleases procedure. SG-II was selected for its high sensitivity for RNA (Fig. 1). SG-II is diluted to $3.5 \times 10^{-4}$ (Fig. 2 ), giving an A480 of $c a$. 0.216. Assays use Tris buffer $\left(5 \mathrm{mM}\right.$ Tris, $0.9 \mathrm{mM} \mathrm{CaCl}_{2}$ and $0.9 \mathrm{mM}$ $\mathrm{MgCl}_{2}$, pH 8.0). Fluorometric readings are performed within 10-60 min following SG-II addition (Fig. 3); meanwhile samples are kept dark at RT. Nuclease incubations are performed in a $37^{\circ} \mathrm{C}$ water bath for $20 \mathrm{~min}$.

A main finding is that the residual fluorescence of the standards was not negligible. Next, we discuss its relevance for natural sample analysis (Section J, and how the final method accounts for residual fluorescence (Section K). We emphasise that standard curves and samples must be processed identically (Section $\mathrm{K}$ ) and that the choice of standards greatly influences calculations of the RNA/DNA ratios (Section I). 


\section{(J) Residual fluorescence: implications for the method}

As explained in Sections $\mathrm{H}$ and I (Tables 1 and 2, Fig. 4), residual RNA and DNA fluorescence after nuclease digestion cannot be completely eliminated despite steps taken to minimise it. It may be related to the capacity of SG-II to bind to very small nucleotide sequences or to the formed nicks (Tabor and Struhl, 1998). However, there is no precise information on the minimum size of RNA or DNA that can result after nuclease digestions. Molecular Probes indicates that as little as 100 pg RNA or single-stranded DNA per band can be detected in a SGII-stained gel. The range of residual fluorescence expected on RNA and DNA standards with the final procedure is $5-15 \%$. In Figure 4 and Table 2, the slopes of the RNA+RNase and DNA+DNase standard curves accounted for the 11.6 and $10.4 \%$ of the slopes of the RNA+DNase and the DNA+RNase ones respectively.

Can we assume that this residual fluorescence observed on RNA and DNA standards is also present in the nuclease assays of the natural samples? What is really measured in the DNase and the RNase assays? Figure 5 and Tables 3 and 4 define and show the relationships between the components of the fluorescence measured in the Tubes A (DNase) and B (RNase) of a natural sample. RNA estimation can be affected by the presence of $\mathrm{d}_{\mathrm{DNA}}$ in Tube A and, the DNA estimation by the presence of $\mathrm{r}_{\mathrm{RNA}}$ in Tube B, if the residual RNA and DNA fluorescences are not negligible. To test this hypothesis we performed the "residual fluorescence" experiment using 10 Engraulis encrasicolus larvae. Each individual larva was processed essentially as outlined in Berdalet et al. (2005); from each homogenate the 5 assays illustrated in Figure 5 were run. Three aliquots were exposed to incubations with DNase (Tube A), RNase (Tube B) and both DNase and RNase (Tube C); the three aliquots were subsequently stained with SG-II. No nuclease incubation was performed in two additional aliquots (Tubes D and E), which were used to estimate the Total (after staining with SG-II) and the Endogenous (left unstained) fluorescences respectively. The addition of the fluorescence values measured in the DNase and the RNase assays (i.e. Tube A + Tube B) and corrected for the "e", "SG" and "o" (null) fluorescences was higher than the Total fluorescence value (Tube D):

$$
\begin{gathered}
\mathrm{Fl}_{\mathrm{A}}+\mathrm{Fl}_{\mathrm{B}}-\mathrm{Fl}_{\mathrm{E}}-\mathrm{SG}-\mathrm{o}=122.2 \% \mathrm{Fl}_{\mathrm{D}} \pm 2.9 \\
(\text { mean } \pm \mathrm{SEM}, \mathrm{n}=10)
\end{gathered}
$$

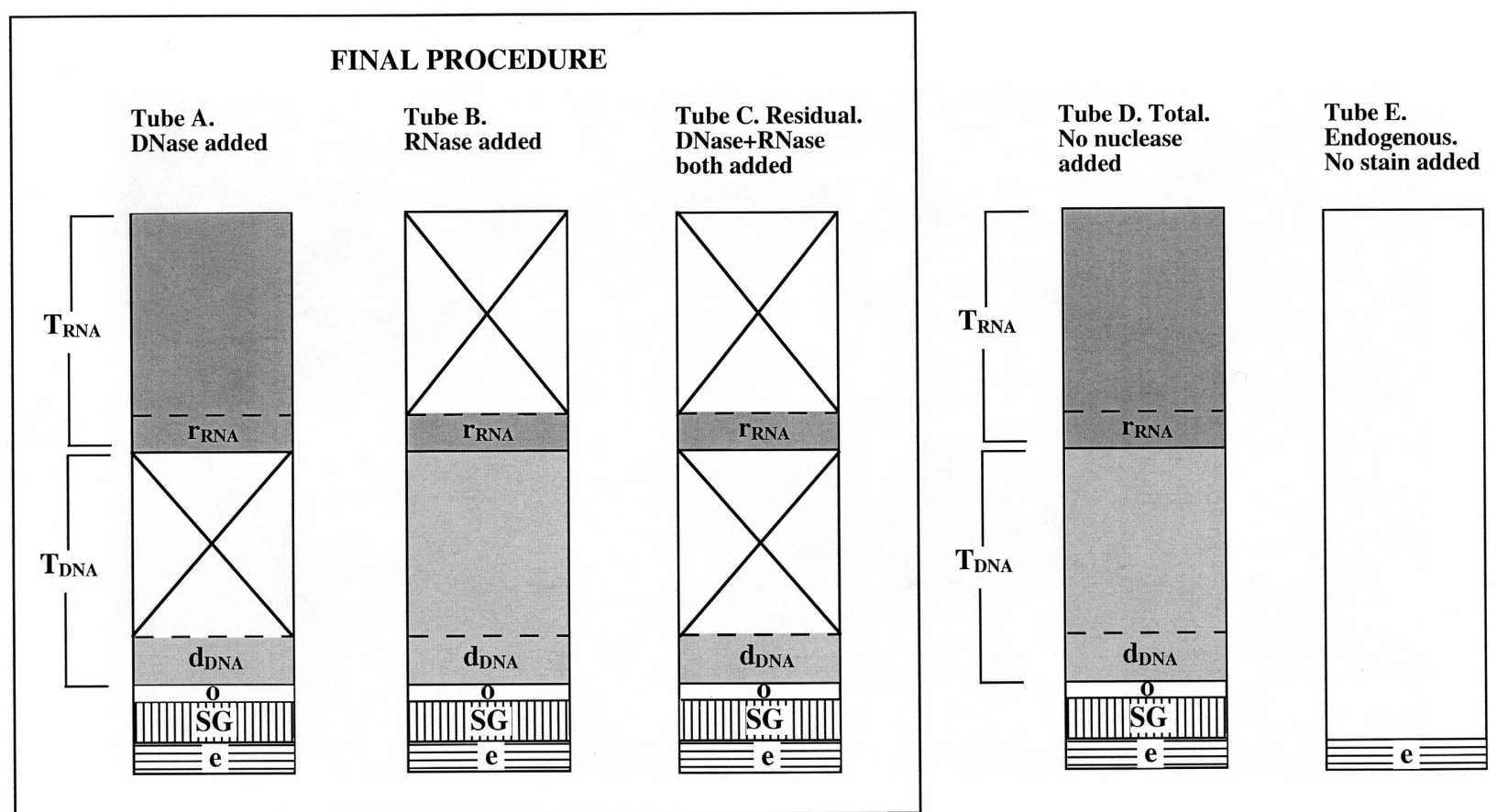

FIG. 5. - Components of the fluorescence measured in test tubes subjected to five different stain and nuclease treatments (section J). Definitions of these components are given in Table 3 and their mathematical relationship in Table 4 . The final protocol requires only the assays in Tubes A, B and C (section K, Fig. 6). Tubes D and E were used in the experiment (section J) aimed at studying the implications of the residual fluorescence. Crossed areas indicate the fluorescence eliminated after the nuclease digestions. 
TABLE 3. - Definitions of the components of the fluorescence used in Figure 5 and Table 4.

e: the endogenous fluorescence, due to the presence of any substance that could absorb energy and produce fluorescence at the $\mathrm{Ex} / \mathrm{Em}$ peak of SG-II. It is insignificant $(<0.5 \%$ of the RNase or the DNase fluorescences).

SG: fluorescence of the unbound SG-II; it corresponds to the yintercept of the standard curves. Its value is slightly lower than the fluorescence of $40 \mathrm{ng} \mathrm{RNA} \mathrm{ml}{ }^{-1}$ or $10 \mathrm{ng} \mathrm{DNA} \mathrm{ml}{ }^{-1}$ (e.g. Fig. 4) stained with SG-II.

o: the fluorescence of other compounds that could bind to SG-II other than nucleic acids. It is insignificant, given the high specificity of SG-II for RNA and DNA (according to Molecular Probes).

$\mathrm{T}_{\mathrm{RNA}}$ : fluorescence due to the Total RNA bound to SG-II.

$\mathrm{T}_{\mathrm{DNA}}$ : fluorescence due to the Total DNA bound to SG-II.

$\mathrm{r}_{\mathrm{RNA}}$ : the residual RNA fluorescence, due to a fraction of RNA that can bind to SG-II after RNase digestion $(\rho)$. Consequently, $\mathrm{r}_{\mathrm{RNA}}=\rho \mathrm{T}_{\mathrm{RNA}}$.

$\mathrm{d}_{\mathrm{DNA}}$ : the residual DNA fluorescence, due to a fraction of DNA that can bind to SG-II after DNase digestion ( $\delta)$. Consequently, $\mathrm{d}_{\mathrm{DNA}}=\delta \mathrm{T}_{\mathrm{DNA}}$.

$$
\begin{aligned}
& \begin{array}{l}
\text { or: } \\
\left(\mathrm{T}_{\mathrm{RNA}}+\mathrm{T}_{\mathrm{DNA}}+\mathrm{o}+\mathrm{SG}+\mathrm{e}\right)+\left(\delta \mathrm{T}_{\mathrm{DNA}}+\rho \mathrm{T}_{\mathrm{RNA}}\right)=
\end{array} \\
& =122.2 \% \mathrm{Fl}_{\mathrm{D}} \pm 2.9
\end{aligned}
$$

This indicates that the residual fluorescence of the natural sample $\left(\delta \mathrm{T}_{\mathrm{DNA}}+\rho \mathrm{T}_{\mathrm{RNA}}\right)$ was not negligible. In contrast, when subtracting the residual assay fluorescence from the DNase plus the RNase assay fluorescences (i.e. Tube A + Tube B - Tube C), the obtained value was very close to the total fluorescence (Tube D):

$$
\begin{gathered}
\mathrm{Fl}_{\mathrm{A}}+\underset{\mathrm{B}}{\mathrm{Fl}_{\mathrm{B}}-\mathrm{Fl}_{\mathrm{C}}=104 \% \mathrm{Fl}_{\mathrm{D}} \pm 1.1} \\
(\text { mean } \pm \mathrm{SEM}, \mathrm{n}=10)
\end{gathered}
$$

The residual RNA and DNA fluorescence of the samples can be accounted for by running a third residual assay with the two nucleases (Tube $\mathrm{C}$ ). The subtraction of the Tube $\mathrm{C}$ fluorescence from Tubes $\mathrm{A}$ and $\mathrm{B}$ (Steps 1 and 3, Section $\mathrm{K}$ ) gives the estimation of the $(1-\rho) \mathrm{T}_{\mathrm{RNA}}$ and the $(1-\delta) \mathrm{T}_{\mathrm{DNA}}$ fluorescence fractions respectively, and also corrects for the interference from other natural compounds ("o"), from the fluorescence of the SG-II ("SG") and from the endogenous fluorescence ("e") (Fig. 5). The value of the $\rho$ and the $\delta$ fractions may vary with the sample, but their exact values are impossible to quantify. It is assumed that the $\rho$ and $\delta$ estimated from the residual fluorescence of the RNA and DNA standard curves are also valid for the natural sam-
TABLE 4. - Mathematical composition of the fluorescence of the five tubes shown in Figure 5. The definitions of these components are given in Table 3 .

\begin{tabular}{ll}
\hline Tube A (DNase): & $\mathrm{Fl}_{\mathrm{A}}=\mathrm{T}_{\mathrm{RNA}}+\mathrm{d}_{\mathrm{DNA}}+\mathrm{o}+\mathrm{SG}+\mathrm{e}$ \\
& $\mathrm{Fl}_{\mathrm{A}}=\mathrm{T}_{\mathrm{RNA}}+\delta \mathrm{T}_{\mathrm{DNA}}+\mathrm{o}+\mathrm{SG}+\mathrm{e}$ \\
Tube B (RNase): & $\mathrm{Fl}_{\mathrm{B}}=\mathrm{T}_{\mathrm{DNA}}+\mathrm{r}_{\mathrm{RNA}}+\mathrm{o}+\mathrm{SG}+\mathrm{e}$ \\
& $\mathrm{Fl}_{\mathrm{B}}=\mathrm{T}_{\mathrm{DNA}}+\rho \mathrm{T}_{\mathrm{RNA}}+\mathrm{o}+\mathrm{SG}+\mathrm{e}$ \\
Tube C (Residual): & $\mathrm{Fl}_{\mathrm{C}}=\mathrm{r}_{\mathrm{RNA}}+\mathrm{d}_{\mathrm{DNA}}+\mathrm{o}+\mathrm{SG}+\mathrm{e}$ \\
& $\mathrm{Fl}_{\mathrm{C}}=\rho \mathrm{T}_{\mathrm{RNA}}+\delta \mathrm{T}_{\mathrm{DNA}}+\mathrm{o}+\mathrm{SG}+\mathrm{e}$ \\
Tube D (Total): & $\mathrm{Fl}_{\mathrm{D}}=\mathrm{T}_{\mathrm{RNA}}+\mathrm{T}_{\mathrm{DNA}}+\mathrm{o}+\mathrm{SG}+\mathrm{e}$ \\
\hline
\end{tabular}

ples (Section K). The error associated with this assumption is equivalent to that of using the slopes $\left(\mathrm{m}_{\mathrm{RNA}+\mathrm{DNase}}\right.$ and $\left.\mathrm{m}_{\mathrm{DNA}+\mathrm{RNase}}\right)$ of standard curves based on a similar fluorescence response of samples and standards. The choice of the standards is of major importance in the comparison of the RNA/DNA ratios obtained in the different studies (Section I).

\section{(K) Final procedure, standard curves and calculations}

\section{Analysis of samples}

The fluorometric quantification of RNA and DNA in a crude plankton extract proceeds according to the following three steps (Fig. 6):

Step 1) Sample distribution: Distribute three aliquots from the extract to run the DNase (Tube A), the RNase (Tube B) and the Residual (Tube C) assays. The volume of extract per assay (e.g. $50 \mu \mathrm{l}$, Fig. 6) can be modified depending on the biomass of the sample, and provided that the concentration of sarcosine (used in the extraction buffer) in the assay was below $0.010 \%$ (Berdalet et al., 2005). Keep test tubes on ice.

Step 2) Nuclease incubation: Add the nuclease WSs (50 $\mu 1$ each per $1 \mathrm{ml}$ assay) and the Tris buffer (the final assay volume after SG-II addition will be $1 \mathrm{ml}$ ). Incubate at $37^{\circ} \mathrm{C}$ for $20 \mathrm{~min}$ and stop the reaction by putting the test tubes back on ice.

Step 3) SG-II addition: Allow the tests tubes to equilibrate at RT for $c a .2$ min in a water bath. Add SG-II WS (50 $\mu \mathrm{l}$ per $1 \mathrm{ml}$ assay) and keep dark at RT until reading. Perform readings within the 10-60 min following staining with either quartz or glass cuvettes at RT at the SG-II Ex/Em peak (a temperature controlled fluorometer cuvette holder is highly recommended). 


\section{EXTRACT}

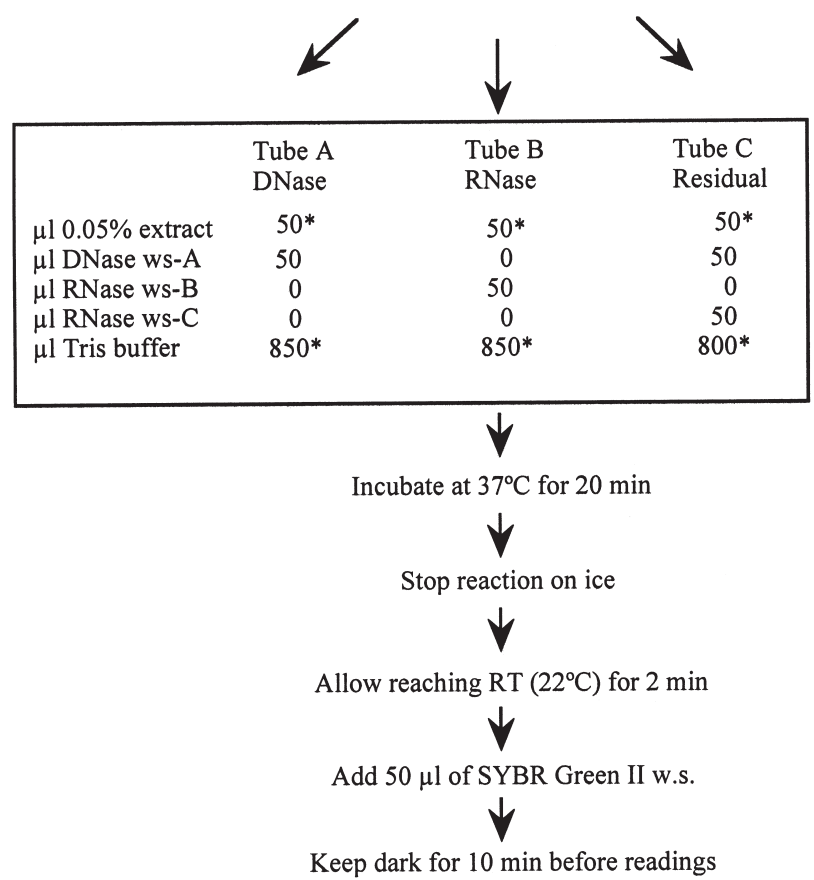

FIG. 6. - Final assay protocol. The asterisks $(*)$ indicate the values that can be changed according to the biomass of the sample.

\section{Standard curves}

Four nucleic acid standard curves (Fig. 4, Table 2) are run for the calculation of the RNA and DNA concentrations in the assays: RNA incubated with DNase (RNA+DNase) or with RNase (RNA+RNase), and DNA incubated with RNase (DNA+RNase) or with DNase (DNA+DNase). They provide the following parameters: $\mathrm{m}_{\mathrm{RNA}+\mathrm{DNase}}$, slope of the RNA+DNase standard curve (Fig. 4a) used in the calculation of the RNA concentration in the samples; $\mathrm{m}_{\mathrm{RNA}+\mathrm{RNase}}$, slope of the RNA+RNase standard curve (Fig. 4a); $\rho=$ $\left(\mathrm{m}_{\mathrm{RNA}+\mathrm{RNase}}\right) /\left(\mathrm{m}_{\mathrm{RNA}+\mathrm{DNase}}\right)$, a ratio that estimates the residual RNA fluorescence fraction ( $\rho$, Fig. 5) used in the calculation of the RNA concentration in the samples $\rho \leq 0.15 ; \mathrm{m}_{\mathrm{DNA}+\mathrm{RNase}}$, slope of the DNA+RNase standard curve (Fig. 4b) used in the calculation of the DNA concentration in the samples; $\mathrm{m}_{\mathrm{DNA}+\mathrm{DNase}}$, slope of the DNA+DNase standard curve (Fig. 4b); and $\delta=$ $\left(\mathrm{m}_{\mathrm{DNA}+\mathrm{DNase}}\right) /\left(\mathrm{m}_{\mathrm{DNA}+\mathrm{RNase}}\right)$, a ratio that estimates the residual DNA fluorescence fraction ( $\delta$, Fig. 5) used in the calculation of the DNA concentration in the samples, $\delta \leq 0.15$.

In running the standard curves, the following factors must be taken into account. They must include the same concentration of the extraction buffer (STEB (1\% sarcosine, $5 \mathrm{mM}$ Tris and $1 \mathrm{mM}$ EDTA, $\mathrm{pH}$ 8.0)) as used in the sample assays (Berdalet et al., 2005), e.g. $0.0025 \%$ in Table 2 . The 4 standard curves illustrated in Figure 4 must be run every day of analysis and their variability must be checked (Section I). For the correct quantification of samples collected on GF/F glass fibre filters (e.g. phytoplankton cultures or microplankton communities) the homogenised filter must be included at least once in each of the 4 standard curves (Fara et al., 1996; Berdalet et al., 2005).

\section{Calculations}

Based on the standard curves run (Fig. 4) and the fluorescence values of the three assays of the samples (Fig. 5), the RNA and DNA concentrations are calculated according to the following four steps:

Step 1) Subtract the fluorescence of Tube $C$ from that of Tube A. The fluorescence of the (1- $\rho)$ fraction of RNA is obtained:

$$
\mathrm{Fl}_{\mathrm{A}}-\mathrm{Fl}_{\mathrm{C}}=\left(\mathrm{T}_{\mathrm{RNA}}-\rho \mathrm{T}_{\mathrm{RNA}}\right)=(1-\rho) \mathrm{T}_{\mathrm{RNA}}
$$

Step 2) Calculate the total RNA concentration:

$$
\mu \mathrm{g} \text { RNA }(\mathrm{ml} \text { assay })^{-1}=\left(\mathrm{Fl}_{\mathrm{A}}-\mathrm{Fl}_{\mathrm{C}}\right) /(1-\rho) / \mathrm{m}_{\mathrm{RNA}+\mathrm{DNase}}
$$

Step 3) Subtract the fluorescence of the Tube C from that of Tube B. The fluorescence of the (1- $\delta$ ) fraction of DNA is obtained:

$$
\mathrm{Fl}_{\mathrm{B}}-\mathrm{Fl}_{\mathrm{C}}=\left(\mathrm{T}_{\mathrm{DNA}}-\delta \mathrm{T}_{\mathrm{DNA}}\right)=(1-\delta) \mathrm{T}_{\mathrm{DNA}}
$$

Step 4) Calculate the total DNA concentration:

$$
\mu \mathrm{g} \text { DNA }(\mathrm{ml} \text { assay })^{-1}=\left(\mathrm{Fl}_{\mathrm{B}}-\mathrm{Fl}_{\mathrm{C}}\right) /(1-\delta) / \mathrm{m}_{\mathrm{DNA}+\mathrm{RNase}}
$$

\section{(L) Selection of standards}

A critical factor in quantitative analysis is the selection of standards which must be as representative as possible of the samples. Unlike other research areas, there is an unfortunate lack of appropriate standards for marine biochemical investigation. As just seen (Sections $\mathbf{J}$ and $\mathrm{K}$ ) the slopes of the selected standard curves and their residual fluorescence will influence the concentration of RNA and DNA estimated in the samples. In addition, the corresponding RNA/DNA ratios will depend on the ratio of the slope of the RNA to that 
TABLE 5. - Coefficient of variation [CV $(\%)=$ standard deviation/mean $x$ 100] of the slopes of the RNA and DNA standard run during several series of analyses (section L). mRNA/mDNA refers to the ratio of the slope of the RNA standard to the slope of the DNA standard run every day of analysis.

\begin{tabular}{|c|c|c|c|c|c|c|c|}
\hline \multirow{2}{*}{$\begin{array}{l}\text { RNA and DNA standards } \\
\text { Group of samples }\end{array}$} & \multicolumn{3}{|c|}{ RNA-Y and DNA-T } & \multicolumn{2}{|c|}{ rRNA-L and uDNA-T } & \multicolumn{2}{|c|}{ rRNA-L and DNA-T } \\
\hline & A & $\mathrm{B}$ & $\mathrm{C}$ & $\mathrm{D}$ & $\mathrm{E}$ & $\mathrm{F}$ & $\mathrm{G}$ \\
\hline Stock of SYBR Green II used & A & $\mathrm{B}$ & $\mathrm{C}$ & $\mathrm{D}$ & $\mathrm{E}$ & $\mathrm{F}$ & $\mathrm{G}$ \\
\hline Number of standards run (n) & 10 & 14 & 4 & 11 & 2 & 5 & 2 \\
\hline Number of days from the 1 st to the last analysis & 32 & 31 & 8 & 17 & 2 & 8 & 2 \\
\hline $\mathrm{CV}(\%)$ of the mRNA & 16.09 & 16.88 & 5.44 & 5.2 & 5.06 & 6.28 & 0.44 \\
\hline $\mathrm{CV}(\%)$ of the mDNA & 6.59 & 8.85 & 0.71 & 17.18 & 14.07 & 9.82 & 8.58 \\
\hline $\mathrm{CV}(\%)$ of the mRNA/mDNA & 16.89 & 9.93 & 4.97 & 13.99 & 9.04 & 10.31 & 8.15 \\
\hline
\end{tabular}

of the DNA standards $\left(\mathrm{m}_{\mathrm{RNA}} / \mathrm{m}_{\mathrm{DNA}}\right)$ used. Thus, the comparison of data requires one to establish the RNA and the DNA standards and the RNA/DNA ratio (or range of ratios) of reference. This question pertains not only to SG-II, but to all fluorometric methods (Caldarone and Buckley, 1991; Caldarone et al., 2001) and is already under study (Berdalet et al., 2005; Caldarone and Clemmesen, pers. comm.).

The choice of standards can be addressed through the comparison of the fluorometric response of the commercially available RNA and DNA standards with that of the natural samples. This approach was used by Fara et al. (1996) in their quantification method based on thiazole orange combined with nucleases. The fluorescent response of the RNA and DNA standards from Escherichia coli was similar to the response displayed by some phytoplankton-extracted nucleic acids. However, these standards had a high day-to-day variability compared to that of the RNA-Y and the DNA-T standards, all with thiazole orange (Berdalet, unpublished), and they were thus discarded in the subsequent study with SG-II.

The day-to-day variability of the fluorescence response of the RNA-Y, rRNA-L, DNA-T and uDNA-T standards bound to SG-II is summarised in Table 5. A single stock solution of SG-II and of RNA and DNA standards was used for the analysis of each group of samples. The DNA-T standard curves performed during the analyses of the $\mathrm{A}$ to $\mathrm{C}$ samples had, in general, lower variability than the uDNA-T samples assayed for the D and E groups, while the RNA-Y samples showed much higher variability than the rRNA- L samples. As a result, rRNA-L and DNA-T were chosen for the F and G series analyses. Their variability trends were coherent with the previous $\mathrm{A}$ to $\mathrm{E}$ series data, and thus rRNA-L and DNA-T are used for calculation purposes in the SG-II final procedure

\section{CONCLUDING REMARKS}

We have presented a study of many aspects of a methodology aimed at quantifying RNA and DNA from crude extracts of marine samples. The details provided can facilitate the adaption of this method to new fluorochromes and/or to other analytical technologies (e.g. fluorescent microplate readers), which would save time, chemicals and sample volume. The election of appropriate standards for the calculations of RNA/DNA ratios is a major challenge. The complete summary of achievements (including the degree of sensitivity and precision attained and the significance of the RNA/DNA ratios), as well as the future research steps, require the application of the whole methodology to natural samples. This is the objective of the accompanying paper (Berdalet et al., 2005), to which we address the reader.

\section{ACKNOWLEDGEMENTS}

This study was supported by the European funded project NTAP (EVK3-CT-2000-00022) and by the Spanish Ministry of Science through the FIL (MAR97 09-02), ARO (MAR-99 12-02) and TURFI (REN2002-01591/MAR) projects. We especially thank Dr. Ted T. Packard for his valuable comments on the manuscript. The suggestions of E. M. Caldarone and of unknown referees markedly improved the final version of the paper. C.R. was funded by the FIL and NTAP projects, the Spanish Ministry of Science and Technology and the European Social Fund. This is ELOISE contribution number 510/40.

\section{REFERENCES}

Bashford, C.L. - 1987. An introduction to spectrophotometry and fluorescence spectrometry. In: C.L. Brashford and D.A: Harris (eds.), Spectrophotometry and spectrofluorimetry: a practical 
approach, Ch. 1, pp. 1-22. IRL Press, Oxford, Washington DC

Bentle, L.A., D. Seshachalam and J. Metcoff. - 1981. The sequential enzymatic determination of RNA and DNA. Anal. Biochem., 116: 5-16.

Berdalet, E. and Q. Dortch. - 1991. New double-staining technique for RNA and DNA measurement in marine phytoplankton. Mar. Ecol. Progr. Ser., 73: 295-305.

Berdalet, E. and M. Estrada. - 1993. Effects of turbulence on several phytoplankton species. In: T. Smayda and Y. Shimizu (eds.), Toxic phytoplankton blooms in the Sea. Developments in Marine Biology, 3. pp. 737-743. 5th International Conference on Toxic Marine Phytoplankton, Rhode Island. USA.

Berdalet, E, C. Marrasé, M. Estrada, L. Arin and M.L. Mac Lean. 1996a. Microbial community responses to nitrogen and phosphorus-deficient nutrient inputs: microplankton dynamics and biochemical characterization. J. Plankton Res., 18: 1627-1641.

Berdalet, E., Arin, L., Marrasé, C., Cruzado, A. and M. Estrada. - 1996b. Limiting nutrients and biochemical composition of natural microbial communities in the NW Mediterranean. 2nd Workshop of the Mediterranean Targeted Project. 5EMMS. Creta.

Berdalet, E. - 2002. Quantization of nucleic acids in marine microplankton samples. In: D.V. Subba Rao (ed.), Pelagic Ecology Methodology, pp. 269-289. A.A. Balkema Publishers, Lisse, Abingdon, Exton (PA), Tokyo.

Berdalet, E., C. Roldán, and M.P. Olivar. - 2005. Quantifying RNA and DNA in planktonic organisms with SG-II and nucleases. Part B. Quantification in natural samples. Sci. Mar., 69:

Bergeron, J.P. - 1997. Nucleic acids in ichthyoplankton ecology: a review, with emphasis on recent advances for new perspectives J. Fish Biol., 51: 284-302.

Buckley, L.J. 1984. RNA - DNA ratios an index of larval growth in the sea. Mar. Biol., 80: 291-298.

Bulow, F.J. - 1970. RNA-DNA ratios as indicators of recent growth rates of a fish. J. Fish. Res. Bd. Can., 27: 2343-2349.

Bulow, F.J. - 1987. RNA-DNA ratios indicators of growth in fish: A review. In: R.C. and G.E. Hall (eds.), The age and growth of fish, pp. 45-64. The Iowa State University Press, Ames, Iowa.

Caldarone, E.M. and L.J. Buckley. - 1991. Quantification of DNA and RNA in crude tissue extracts by flow injection. Anal. Biochem., 199: 137-141.

Caldarone, E.M., M. Wagner, J. St. Onge-Burns and L.J. Buckley. - 2001. Protocol and guide for estimating nucleic acids in larval fish using a fluorescence microplate reader. Northeast Fish. Sci. Cent. Ref. Doc., 01-11: 1-22. http://www.nefsc.nmfs.gov/ nefsc/publications/.

Canino, M.F., K.M. Bailey and L.S. Incze. - 1991. Temporal and geographical differences in feeding and nutritional condition of walleye pollock larvae Theragra chalcogramma in Shelikof Strait, Gulf of Alaska. Mar. Ecol. Progr. Ser., 79: 27-35.

Ceasarone, C.F., C. Bolognesi and L. Santi. - 1979. Improved microfluorimetric DNA determination in biological material using 33258 Hoeschst. Anal. Biochem., 100: 188-197.

Clemmesen, C. -1994 . The effect of food availability, age or size on the RNA/DNA ratio of individually measured herring larvae: laboratory calibration. Mar. Biol., 118: 377-382.

Dagg, M.J. and J.L. Littlepage. - 1972. Relationships between growth rate and RNA, DNA, protein and dry weight in Artemia salina and Euchaeta elongata. Mar. Biol., 17: 162-170.

Dortch, Q., T.L. Roberts, J.R. Clayton, Jr. and S.I. Ahmed. - 1983. RNA/DNA ratios and DNA concentrations as indicators of growth rate and biomass in planktonic marine organisms. Mar. Ecol. Prog. Ser., 13: 61-71.

Fara, A., E. Berdalet, and L. Arin. - 1996. Determination of RNA and DNA concentrations in natural plankton samples using thiazole orange in combination with DNase and RNase digestions. J. Phycol., 32: 1074-1083.

Folkvord, A., L. Ystanes and E. Moksness. - 1996. RNA:DNA ratios and growth of herring (Clupea harengus) larvae reared in mesocosms. Mar. Biol., 126: 591-602.

Gorokhova, E. and M. Kyle. - 2002. Analysis of nucleic acids in Daphnia: development of methods and ontogenic variations in RNA-DNA content. J. Plankton Res., 24: 511-522.

Haugland, R.P. - 2002. Nucleic Acid Detection and Genomics Technology. In: J. Gregory (ed.), Handbook of Fluorescent Probes and Research Products, pp. 265-352. Molecular Probes, Inc. USA.

Holm-Hansen, O., W.H. Sutcliffe, Jr. and J. Sharp. - 1968. Mea- surement of the deoxyribonucleic acid in the ocean and its ecological significance. Limnol. Oceanogr., 13: 507-514.

Kemp, P.F., Lee, S. and J. La Roche. - 1993. Estimating the growth rate of slowly growing marine bacteria from RNA content. Appl. Environm. Microbiol., 59: 2594-2601.

Klinger, T.S., S.A. Watts and D. Forcucci. - 1988. Effect of short-term feeding and starvation on storage and synthettic capacities of gut tissues of Lytechinus variegatus (Lamarck) (Echinodermata:Echinoidea). J. Exp. Mar. Biol. Ecol., 117: 187-195.

Kuropat, C., R. Mercaldo-Allen, E.M. Caldarone, R. Goldberg, B. Phelan and F. Thurberg. - 2002. Evaluation of RNA concentration as an indicator of growth in young-of-the-year winter flounder Pseudopleuronectes americanus and tautog Tautoga onitis. Mar. Ecol. Progr. Ser., 230: 265-274.

Le Pecq, J.B. and C. Paoletti. - 1966. A new fluorimetric method for RNA and DNA determination. Anal. Biochem., 17: 100107

Lysnes, K. - 1998. Determination of DNA and RNA in marine plankton samples. Master thesis, Univ. Bergen, Norway.

Marie, D., D. Vaulot and F. Partensky. - 1996. Application of the novel nucleic acid dyes YOYO1, YO-PRO-1 and Pico-Green for flow cytometric analysis of marine prokaryotes. Appl. Environ. Microbiol., 62: 1649-1655.

Mathers, E.M., D.F. Houlihan and L.J. Burren. - 1994. RNA, DNA and protein concentrations in fed and starved herring Clupea harengus larvae. Mar. Ecol. Progr. Ser., 107: 223-231.

Mordy, C.W. and D.J. Carlson. - 1991. An evaluation of fluorescence techniques for measuring DNA and RNA in marine microorganisms. Mar. Ecol. Prog. Ser., 73: 283-293.

Munro, H. N. and A. Fleck. - 1966. The determination of nucleic acids. In: D. Glick (ed.), Methods of Biochemical Analysis, pp. 113-176. Interscience Publishers, New York.

Nakata, K., H. Nakano and H. Kikuchi. - 1994. Relationship between egg productivity and RNA/DNA ratio in Paracalanus sp. In the frontal waters of the Kurshio. Mar. Biol. 119: 591-596.

Nobel, R.T. and J.A. Furhman. - 1997. Use of SYBR Green I for use of rapid epifluorescence counts of marine viruses and bacteria. Aquat. Microb. Ecol. 14: 113-118.

Regnault, M. and P. Luquet. - 1974. Study by evolution of nucelic acid content of prepuberal growth in the shrimp Crangon vulgaris. Mar. Biol., 25: 291-298.

Saiz, E., A. Calbet, A. Fara. and E. Berdalet. - 1998. RNA content of copepods as a tool for determining adult growth rates in the field Limnol. Oceanogr., 43: 465-470.

Sambrook, J., E.F. Fritsch and T. Maniatis. - 1989. Molecular cloning: A laboratory manual, C. Nolan (ed.). Cold Spring Harbor Laboratory Press, USA.

Schmidt, G. and S.J. Tannhauser. - 1945. A method for the determination of deoxyribonucleic acid, ribonucleic acid, and phosphoproteins in animal tissues. J. Biol. Chem., 161: 83-89.

Schmidt, D.M. and J.D. Ernst. - 1995. A Fluorometric assay for the quantification of RNA in solution with nanogram sensitivity. Anal. Biochem., 232: 144-146.

Sutcliffe, W.H.J. - 1970. Relationship between growth rate and ribonucleic acid concentration in some invertebrates. J. Fish. Res. Bd. Can., 27: 606-609.

Suthers, I.M., J.J. Cleary, S.C. Battaglene and R. Evans. - 1996. Relative RNA content as a measure of condition in larval and juvenile fish. Mar. Freshwater Res., 47: 301-307.

Tabor, S. and K. Struhl. - 1998. Endonucleases. In: F.M. Ausubel, R. Brent, R.E. Kingston, D.D. Moore, J.G. Seidman, J.A. Smith and K. Struhl (eds.), Current protocols in molecular biology. Vol. I. pp. 3.12.1-3.12.6. John Wiley and Sons, Inc. USA.

Thoresen, S.S., J.R. Clayton, Q. Dortch and S.I. Ahmed. - 1983. A rapid technique for the determination of RNA and DNA in marine phytoplankton. J. Plankton Res., 5: 253-261.

Veldhuis, M.J.W., T.L. Cucci and M.E. Sieracki. - 1997. Cellular DNA content of marine phytoplankton using two new fluorochromes: taxonomic and ecological implications. J. Phycol., 33: 527-541.

Vrede, T., J. Persson and G. Aronsen. - 2002. The influence of food quality $(\mathrm{P}: \mathrm{C})$ ratio and somatic growth rate of Daphnia. Limnol. Oceanogr., 47: 487-494.

Walser, R. and H. Güde. - 1994. DNA and RNA contents of bacteria-sized particles from Lake Constance. Arch. Hydrobiol., 131: 257-276. 
Wagner, M., E. Durbin. and L. Buckley. - 1998. RNA:DNA ratios as indicators of nutritional condition in the copepod Calanus finmarchicus. Mar. Ecol. Prog. Ser., 162: 173-181.

Westerman, M. and G. Holt. - 1994. RNA:DNA ratio during the critical period and early larval growth of the red drum Sciaenops ocellatus. Mar. Biol., 121: 1-9.

Scient. ed.: T.T. Packard

16 E. BERDALET et al. 